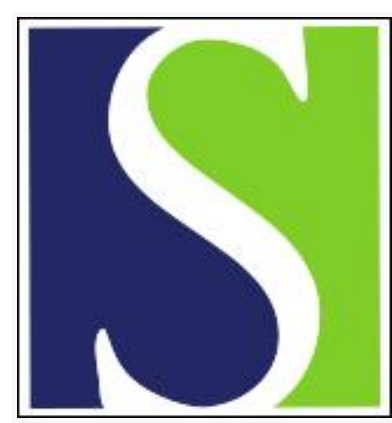

Scand J Work Environ Health 1991;17(3):159-169

https://doi.org/10.5271/sjweh.1715

Issue date: Jun 1991

A collaborative study of cancer incidence and mortality among vinyl chloride workers.

by Simonato L, L'Abbe KA, Andersen A, Belli S, Comba P, Engholm G, Ferro G, Hagmar L, Langard S, Lundberg I, et al.

Affiliation: International Agency for Research on Cancer, Lyon, France.

This article in PubMed: www.ncbi.nlm.nih.gov/pubmed/2068554 


\title{
A collaborative study of cancer incidence and mortality among vinyl chloride workers
}

\author{
by $\mathrm{L}$ Simonato, MD, ${ }^{1,2} \mathrm{KA}$ L'Abbé, PhD, ${ }^{1,3} \mathrm{~A}$ Andersen, MD, ${ }^{4} \mathrm{~S}$ Belli, DSc, ${ }^{5} \mathrm{P}$ Comba, DSc, ${ }^{5}$ \\ G Engholm, ${ }^{6} \mathrm{G}$ Ferro, ${ }^{1} \mathrm{~L}$ Hagmar, $\mathrm{MD},{ }^{7} \mathrm{~S}$ Langård, MD, PhD,${ }^{8}$ I Lundberg, $\mathrm{MD},{ }^{9}$ \\ $\mathrm{R}$ Pirastu, MSc, ${ }^{10} \mathrm{P}$ Thomas, BSc, ${ }^{11} \mathrm{R}$ Winkelmann, MA, ${ }^{1} \mathrm{R}$ Saracci, MD, ${ }^{1}$
}

\begin{abstract}
SIMONATO L, L'ABBÉ KA, ANDERSEN A, BELLI S, COMBA P, ENGHOLM G, FERRO G, HAGMAR L, LANGÅRD S, LUNDBERG I, PIRASTU R, THOMAS P, WINKELMANN R, SARACCI R. A collaborative study of cancer incidence and mortality among vinyl chloride workers. Scand J Work Environ Health 1991;17:159-69. A large European multicentric cohort study has been coordinated by the International Agency for Research on Cancer with the objectives of investigating the dose-response relationship between liver cancer and exposure to vinyl chloride and assessing cancer risk for sites other than the liver. A nearly threefold increase in liver cancer was detected on the basis of 24 observed deaths and 8.4 expected (standardized mortality ratio $286,95 \%$ confidence interval 186-425). The excess from liver cancer was clearly related to time since first exposure, duration of employment, and estimated ranked and quantitative exposures. Other cancer sites investigated on the basis of a priori hypotheses were either not in excess (lung) or apparently unrelated to the exposure variables (brain and lymphoma).
\end{abstract}

Key terms: brain cancer, cohort study, dose-response relationship, liver cancer, lung cancer, lymphoma.

Vinyl chloride (VC) is an established carcinogen for humans $(1,2)$, and it is also one of the few substances for which the experimental evidence of carcinogenicity was available (3) before the carcinogenic effects on humans could be demonstrated.

The concern about the hazards from exposure to this substance led to control measures which lowered the levels of exposure in excess of $500 \mathrm{ppm}$ in the early 1950 s to values generally below $1 \mathrm{ppm}$ in industrialized countries.

In recent years, the development of laboratory techniques in investigating possible effects at the molecu-

1 International Agency for Research on Cancer, Lyon, France.

2 Present address: Registro Tumori del Veneto, University of Padova, Italy.

${ }^{3}$ Present address: Department of Preventive Medicine and Biostatistics, University of Toronto, Toronto, Ontario, Canada.

4 The Cancer Registry of Norway, Oslo, Norway.

5 National Institute of Health, Rome, Italy.

${ }^{6}$ The Construction Industry's Organization for Working Environment, Safety and Health, Bygghalsan, Danderyd, Sweden.

7 Department of Occupational Medicine, University Hospital, Lund, Sweden.

8 Telemark Central Hospital, Department of Occupational Medicine, Porsgrunn, Norway.

${ }^{9}$ Karolinska Hospital, Department of Occupational Medicine, Stockholm, Sweden.

10 Department of Animal and Human Biology, University of Rome, La Sapienza, Rome, Italy.

${ }^{11}$ Health and Safety Executive, Employment Medical Advisory Service, Bootle, United Kingdom.

Reprint requests to: Dr R Saracci, Unit of Analytical Epidemiology, International Agency for Research on Cancer, 150 Cours Albert-Thomas, F-69372 Lyon cédex 08, France. lar level (4) renewed the interest in this substance. In addition the epidemiologic data have recently been updated (5-7) and reevaluated in a review (8).

Although occupational exposures have decreased, important scientific and public health questions remain. In 1986 the occupational program of the International Agency for Research on Cancer (IARC) invited European epidemiologists involved in research on the effects of VC to combine their efforts in a multicentric cohort study. The collaborative cohort study reported in this presentation was undertaken with the following three objectives: (i) to determine whether VC is associated with increased cancer risk at sites other than the liver, (ii) to investigate the possible exposure-response relationship between VC and liver cancer, particularly angiosarcoma of the liver, and (iii) to construct a data base which could be exploited in the future in relation to the assessment of potential risk at low levels of exposure.

In this report, we present the methods and results of this collaborative study, further details of which can be found in an IARC report (9).

\section{Subjects and methods}

Collaborators from four countries (Italy, Norway, Sweden, and the United Kingdom) participated in the cohort study and contributed a total of 14351 subjects to the combined data base. Both existing studies and newly collected cohorts were enrolled from 19 factories. Where existing study populations were included (10-15) follow-up was extended, and/or more factories were added. In the majority of factories in the cohort there was mixed VC monomer/polyvinyl chlo- 
ride (VCM/PVC) production (12 factories), two produced VCM only, four produced PVC only, and one was a PVC-processing plant.

For the sake of homogeneity, we decided to include only subjects with at least one year of employment in the analysis, and therefore 1518 subjects $(10.6 \%$ of the combined cohort) had to be excluded. An additional 127 subjects $(0.9 \%$ of the combined cohort) were excluded for the following reasons: female gen$\operatorname{der}(\mathrm{N}=57)$, out of observation period $(\mathrm{N}=48)$, member of more than one cohort $(\mathrm{N}=21)$, and date of first exposure unknown $(\mathrm{N}=1)$. After the total of $1645 \mathrm{ex}$ clusions (11.5\% of the combined data base), 12706 subjects remained for the analysis.

The vital status of the subjects included in the mortality analysis is shown in table 1 , and the completeness of follow-up at $97.7 \%$ can be considered satisfactory. For the 12706 subjects included in the analysis, the average length of follow-up was 17 (range $10-25$ ) years, $36 \%$ of the cohort having a follow-up period of 20 years or more. The total number of person-years at risk was 222746 , and the distribution of person-years according to duration and the number of years since first exposure is given in table 2 .

National incidence or mortality rates (men only) specific for age and five-year calendar periods were used for reference. The observation period differed by factory, the majority of subjects having been followed from 1955 (first year for which reference rates were available) or from the start of the second year of employment, whichever came first, to 1986 . Two of the four countries, Norway and Sweden, were also able to provide follow-up for incidence through nationbased cancer registries, while mortality rates were computed at IARC with the use of a data base belonging to the World Health Organization (WHO). As different revisions of the International Classification of Diseases (ICD) were used over the follow-up period,

Table 1. Vital status of the cohort members. ${ }^{a}$

\begin{tabular}{lrr}
\hline Vital status & $\mathrm{N}$ & $\%$ \\
\hline Alive & 10981 & 86.4 \\
Dead & 1438 & 11.3 \\
Unknown (lost or emigrated) & 287 & 2.3 \\
Total & 12706 & 100 \\
\hline
\end{tabular}

a Person-years at risk: 222746 .

Table 2. Person-years by duration of employment and followup.

\begin{tabular}{lrrrrr}
\hline $\begin{array}{l}\text { Duration of } \\
\text { employment } \\
\text { (years) }\end{array}$ & \multicolumn{4}{c}{ Years since first exposure } & Total \\
\cline { 2 - 5 } & $1-9$ & $10-19$ & $20-29$ & $\geq 30$ & \\
\hline $1-9$ & 95178 & 43306 & 13293 & 2670 & 154446 \\
$10-19$ & - & 43256 & 8842 & 1427 & 53526 \\
$\geq 20$ & - & - & 11810 & 2965 & 14775 \\
\hline Total & 95178 & 86562 & 33945 & 7062 & 222746 \\
\hline
\end{tabular}

a conversion table for causes of death was used and can be found in the detailed IARC report (9).

It should be noted that for this study liver cancer was defined as ICD 155-156 (seventh revision): liver, intrahepatic and extrahepatic bile ducts, and gallbladder specified as primary or secondary; ICD 155 (eighth revision): liver and intrahepatic bile ducts specified as primary; and ICD 155 (ninth revision): liver and intrahepatic bile ducts specified as primary and liver specified as secondary. Although ideally only primary liver cancer should be chosen as the definition, the seventh and ninth ICD revisions do not permit separation of primary and secondary (as this distinction is often difficult in reality). In the eighth and ninth revisions, secondary liver cancer is classified by a fourdigit code, but specification of the national mortality rates to four digits in the WHO data base is not available from all countries. Therefore, it was necessary to choose the aforementioned definition for liver cancer.

Angiosarcoma of the liver is distinguished from other types of liver cancer through histology. This type of information was sought from national investigators, and only cases histologically confirmed were included in the analyses.

For the analysis, person-years at risk were calculated with the person-years program using a modified lifetable approach (16). In calculating the person-years, no censoring at old age took place, and the date of entry for the tabulation of person-years started at the beginning of the observation period according to the availability of reference rates in 1955 or on day 1 of the second year of employment, whichever occurred later.

The standardized mortality ratio (SMR) or standardized incidence ratio (SIR) and the $95 \%$ confidence interval $(95 \% \mathrm{CI})$ for the SMR or SIR were calculated on the assumption of a Poisson distribution. Prior to the analysis, it was decided that four causes of death suspected a priori (ie, liver cancer, lung cancer, brain cancer, and lymphosarcoma) would be examined in detail.

The mortality analysis was performed according to several temporal variables, specifically years since first exposure, calendar period at hire, calendar period at exit, age at hire, and age at exit. In the analysis all of these variables were based on individual information available for each subject. Exposure variables were job title as autoclave worker (ever/never), duration of employment, ranked level of exposure, and cumulative exposure in parts per million-years to VCM in the air.

For the ranked level of exposure and cumulative exposure indices, job histories were required, along with exposure estimates for specific jobs and calendar periods from job-exposure matrices. The job-exposure matrices specific for calendar period were provided by industrial hygienists for 13 of the 19 factories. These matrices were developed in various ways for the different factories. For most of them, job title was used as the basic unit with which exposure was assessed, and 
job histories were available for all factories except two. "Typical exposures" to VC in air were estimated as time-weighted averages by industrial hygienists using several sources of variable quality. In most factories, occasional measurements of VC provided the basis for past typical exposures, supplemented by knowledge of exposure conditions, processes, and technological changes over time. Systematic measurements taken since the mid-1970s provided the basis for more recent exposure assessments, and an indication of the variability of exposure levels between job titles.

In terms of agents to which the workers were exposed in VCM, PVC, and VCM/PVC production, VC was the main exposure, and virtually the only exposure in many of these factories. Use of butadiene was rare. In PVC processing (one factory in this study), however, additional exposures could have included PVC dust, asbestos, and other agents. All the job-exposure matrices referred only to VC exposure in air.

Each job-exposure matrix was checked and validated by two independent industrial hygienists, who were able to provide, prior to the statistical analysis, an index for the ranked level of exposure (low: $<50 \mathrm{ppm}$; intermediate: $50-449 \mathrm{ppm}$; and high: $\geq 500 \mathrm{ppm}$ ) in which the classification of the subjects was based on the highest level to which the workers were potentially exposed, specific to their jobs and the years in which they worked, according to levels of $\mathrm{VC}$ recorded in the job-exposure matrices.

The same information, that is, job histories and jobexposure matrices, was used to calculate cumulative exposure in parts per million-years (exposure level from the job-exposure matrices multiplied by duration of employment) for the subjects. In some of the analyses for cancer of the liver an estimated job-exposure matrix was used for the four factories in the United Kingdom which were unable to provide their own matrices. The estimated job-exposure matrix was based on the matrices provided for the other factories in the United Kingdom. This matrix was checked with the industrial hygienist from the United Kingdom. In the following text, it is clearly noted if the analyses under discussion include this estimated matrix.

For liver cancer only, the Poisson regression analysis was performed to assess the significance of several variables simultaneously. This analysis used observed deaths and the person-years distribution for crossclassified categories of temporal and exposure variables and performed an internal comparison with the base-line categories (ie, within the cohort only) $(17,18)$.

\section{Mortality results}

Cause-specific mortality for the total cohort is presented in table 3. A statistically significant deficit for all-cause mortality was apparent (1438 deaths observed versus 1636.4 expected, SMR 88, $95 \%$ CI 83-93). The following four main causes of death contributed to this deficit: (i) diseases of the circulatory system, (ii) diseases of the respiratory system, (iii) accidents, poisonings and violence, and (iv) other known causes.

For all malignant neoplasms, the SMR was 104 (95\% CI 95-114), with 445 deaths observed. However, there were two causes of death, both cancers, which showed statistically significant excesses. They were cancer of the liver with 24 observed deaths and 8.4 expected (SMR 286, $95 \%$ CI 183-425) and cancer of an unspecified site with 24 observed deaths and 12.9 expected (SMR 187, $95 \%$ CI 120-278). Increases which were not statistically significant were apparent for bladder cancer (21 deaths observed, SMR 146, $95 \%$ CI 91-224), malignant melanoma (7 deaths observed, SMR 163, $95 \%$ CI 65-335), and lymphosarcoma (7 deaths observed, SMR 170, $95 \%$ CI 69351).

In this report the results are not given by process. The statistically significant excess of liver cancer evident in the total cohort was mainly due to the excess in VCM/PVC production (19 deaths observed, SMR $311,95 \%$ CI 187-486).

Twenty-three sites were selected for analysis according to the years since first exposure, and the results for 10 of these sites are presented in table 4. Apart from liver cancer, which will be discussed in detail, there were no noteworthy patterns in risk according to this variable.

Four sites were investigated in detail for relationships with temporal and exposure variables. Of the two sites with excess risk for the total cohort, cancer of an unspecified site was not analyzed further due to the diversity of cancers found in this category; they are however discussed in a descriptive fashion in the text. Liver cancer, lung cancer, brain cancer, and lymphosarcoma were chosen a priori for further analysis. Excesses of bladder cancer in PVC production (in the United Kingdom) and of melanoma (in Norway) were not investigated further for the total cohort since they were confined to one country.

\section{Liver cancer}

No liver cancer deaths occurred before 15 years since first exposure, after which the SMR was $483(95 \%$ CI 208-951) for 15-19 years since first exposure, and it did not vary greatly from this level thereafter, the value always being statistically significant. In table 4 , the pattern by years since first exposure is seen in 10 -year groups. When only those with 15 years since first exposure or more were included in the analysis (15-year latency), the overall SMR for liver cancer was 445 (95 \% CI 285-663).

Table 5 shows the SMR values for liver cancer according to the four exposure variables, without and with a 15-year latency analysis. According to job title, dichotomous as ever autoclave worker (suspected a priori as the highest risk job) versus never an autoclave worker, very high risk was experienced by those who 
Table 3. Mortality by detailed cause. $(\mathrm{O}=$ observed number of deaths, $\mathrm{E}=$ expected number of deaths, $\mathrm{SMR}=$ standardized $\mathrm{mor}$ tality ratio, $95 \% \mathrm{Cl}=95 \%$ confidence interval)

\begin{tabular}{|c|c|c|c|c|}
\hline Cause of deatha & 0 & E & SMR & $95 \% \mathrm{Cl}^{\mathrm{b}}$ \\
\hline All causes $(000-999)$ & 1438 & 1636.4 & 88 & $83-93$ \\
\hline All malignant neoplasms $(140-207)$ & 445 & 427.8 & 104 & $95-114$ \\
\hline Buccal cavity and pharynx (140-149) & 7 & 9.8 & 72 & $29-148$ \\
\hline Esophagus (150) & 9 & 12.1 & 75 & $34-142$ \\
\hline Stomach $(151)$ & 49 & 45.1 & 109 & $80-144$ \\
\hline Intestine, except rectum (152-153) & 21 & 25.9 & 81 & $50-124$ \\
\hline Rectum (154) & 15 & 17.6 & 85 & $48-141$ \\
\hline Liver and intrahepatic bile ducts (155) & 24 & 8.4 & 286 & $183-425$ \\
\hline Pancreas (157) & 16 & 19.3 & 83 & $47-135$ \\
\hline Larynx (161) & 5 & 7.3 & 68 & $22-159$ \\
\hline Trachea, bronchus and lung (162) & 144 & 148.3 & 97 & $82-114$ \\
\hline Bone (170) & 3 & 2.5 & 120 & $25-352$ \\
\hline Connective and other soft tissue (171) & 0 & 1.4 & 0 & $0-265$ \\
\hline Melanoma of skin (172) & 7 & 4.3 & 163 & $65-335$ \\
\hline Prostate (185) & 21 & 20.2 & 104 & $64-159$ \\
\hline Testis (186) & 3 & 2.5 & 118 & $24-345$ \\
\hline Bladder (188) & 21 & 14.3 & 146 & $91-224$ \\
\hline Kidney (189) & 4 & 10.0 & 40 & $11-103$ \\
\hline Brain (191) & 14 & 13.1 & 107 & $59-180$ \\
\hline Thyroid (193) & 2 & 1.1 & 181 & $22-654$ \\
\hline Unspecified site (199) & 24 & 12.9 & 187 & $120-278$ \\
\hline Lymphosarcoma (200) & 7 & 4.1 & 170 & $69-351$ \\
\hline Hodgkins disease (201) & 7 & 5.3 & 133 & $53-274$ \\
\hline Leukemia $(204-207)$ & 11 & 13.4 & 82 & $41-147$ \\
\hline Other lymphatic neoplasms $(202-203)$ & 4 & 9.9 & 40 & $11-104$ \\
\hline Other malignant neoplasms & 27 & 19.3 & 140 & $92-204$ \\
\hline Benign and unspecified neoplasms $(210-239,208)$ & 4 & 6.6 & 61 & $17-155$ \\
\hline Circulatory system $(390-458)$ & 622 & 712.8 & 87 & $81-94$ \\
\hline Respiratory system $(460-519)$ & 108 & 140.9 & 77 & $63-93$ \\
\hline Digestive system $(520-577)$ & 72 & 77.2 & 93 & $73-117$ \\
\hline Chronic liver disease, cirrhosis (571) & 35 & 39.7 & 88 & $61-123$ \\
\hline Accidents, poisonings and violence (E800-E999) & 114 & 144.0 & 79 & $65-95$ \\
\hline Other known causes & 73 & 127.0 & 57 & $45-72$ \\
\hline
\end{tabular}

a Code of the International Classification of Diseases (eighth revision) in parentheses.

b Based on a Poisson distribution.

were autoclave workers at some time (SMR 896, $95 \%$ CI 447-1603). In the analysis with a 15-year latency period, a statistically significant increased risk was also apparent for those classified as "never an autoclave worker," a group which however included workers with job "unspecified" also.

Duration of employment was associated with an increasing mortality trend from liver cancer, which was statistically significant $\left(\chi^{2} 19.5, \mathrm{P}<0.001\right)$. With a 15 -year latency period, the trend was not as strong $\left(\chi^{2} 5.70, P<0.025\right)$.

A very clear exposure-response relationship was seen for ranked level of exposure and liver cancer mortality. Although the ranked level of exposure was unknown for six deaths, increasing risk at progressively increasing levels of exposure was demonstrated $\left(\chi^{2}\right.$ $7.99, \mathrm{P}<0.01)$. With the use of a 15 -year latency period and the estimated job-exposure matrices from factories 10 through 13 from the United Kingdom, the SMR for the intermediate category $(50-499 \mathrm{ppm})$ was also statistically significant ( 7 deaths observed, SMR 551, $95 \%$ CI 222-1136). The risk clearly increased with increasing total cumulative exposure to $\mathrm{VC}$ in parts per million-years $\left(\chi^{2} 20.4, \mathrm{P}<0.001\right)$. An analysis with a five-year lag in cumulative exposure made virtually no difference in any of the results, and therefore the data are not presented. The results of the multivariate analysis for liver cancer in an internal comparison are presented in table 6 . Only two variables, years since first exposure and cumulative exposure, had a statistically significant effect on the risk of liver cancer mortality.

Risk increased steadily with increasing exposure when years since first exposure was adjusted for. The tests for interactions were not statistically significant, and the addition of a quadratic term for cumulative exposure did not improve the fit of the model. The same procedure was followed when cumulative exposure from the estimated job-exposure matrix for the factories from the United Kingdom was included, and the regression results were similar. The relative risk estimates varied slightly from the previous model, probably because of the effect of misclassification from the job-exposure matrices of the four factories whose matrices were developed from those of other factories.

\section{Angiosarcoma of the liver}

Major characteristics of the 24 liver cancer deaths certified in the mortality data as ICD code 155 (eighth and ninth revision, as no death was coded according to the seventh revision) can be seen in table 7 . When 
Table 4. Mortality by time since first exposure for selected sites. $(O=$ observed number of deaths, $E=$ expected number of deaths, SMR = standardized mortality ratio, $95 \% \mathrm{Cl}=95 \%$ confidence interval)

\begin{tabular}{|c|c|c|c|c|c|c|c|c|c|c|c|c|c|c|c|}
\hline \multirow{3}{*}{$\begin{array}{l}\text { Cause of } \\
\text { death }\end{array}$} & \multicolumn{15}{|c|}{ Years since first exposure } \\
\hline & \multicolumn{3}{|r|}{$1-9$} & \multicolumn{3}{|r|}{$10-19$} & \multicolumn{3}{|r|}{$20-29$} & \multicolumn{3}{|r|}{$\geq 30$} & \multicolumn{3}{|r|}{ Total } \\
\hline & 0 & $\mathrm{E}$ & SMR $95 \% \mathrm{Cl}$ & 0 & $\mathrm{E}$ & SMR $95 \% \mathrm{Cl}$ & 0 & E & SMR $95 \% \mathrm{Cl}$ & 0 & E & SMR $95 \% \mathrm{Cl}$ & 0 & E & SMR $95 \% \mathrm{Cl}$ \\
\hline
\end{tabular}

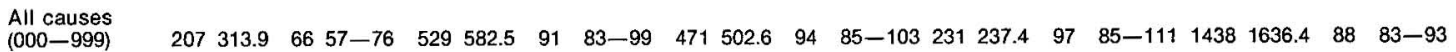

All malignant

neoplasms

$(140-207)$

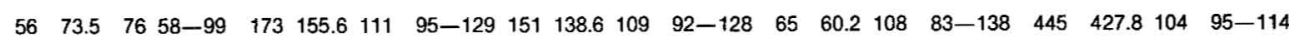

Liver and

intrahepatic

bile ducts

(155)

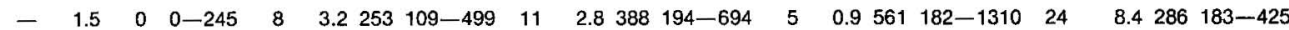

Trachea,

bronchus

and lung

$\begin{array}{llllllllllllllllllllllll}(162) & 16 & 22.7 & 71 & 40-114 & 50 & 53.9 & 93 & 69-122 & 60 & 50.4 & 119 & 91-153 & 18 & 21.3 & 84 & 50-133 & 144 & 148.3 & 97 & 82-114\end{array}$

$\begin{array}{lllllllllllllllllllll}\text { Bladder (188) } \quad 2 & 1.8 & 109 & 13-395 & 7 & 4.8 & 146 & 59-301 & 6 & 5.1 & 117 & 43-255 & 6 & 2.6 & 231 & 85-504 & 21 & 14.3 & 146 & 91-224\end{array}$

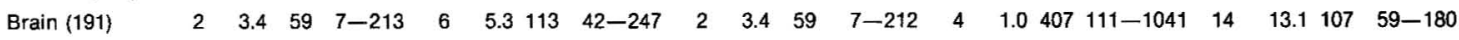

Lympho-

sarcoma

(200)

Circulatory

system
$(390-458)$

Respiratory

system

$(460-519)$

$3 \quad 1.322546-657 \quad 4 \quad 1.6258 \quad 70-662-1.0 \quad 0 \quad 0-381 \quad-\quad 0.3 \quad 0 \quad 0-1430 \quad 7 \quad 4.1170 \quad 69-351$

Chronic liver

disease,

cirrhosis

(571)

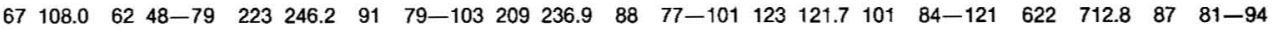

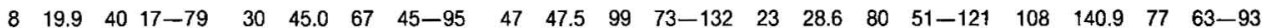

a Code of the International Classification of Diseases (eighth revision) in parentheses.

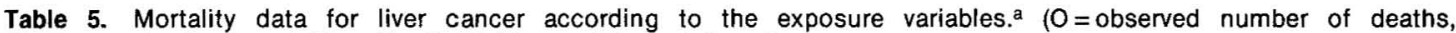
SMR $=$ standardized mortality ratio, $95 \% \mathrm{Cl}=$ confidence interval)

\begin{tabular}{|c|c|c|c|c|c|c|c|c|}
\hline \multirow{2}{*}{ Exposure variable } & \multirow{2}{*}{\multicolumn{2}{|c|}{$\mathrm{O}^{\mathrm{a}}$}} & \multirow{2}{*}{ SMR } & \multirow{2}{*}{$95 \% \mathrm{Cl}$} & \multicolumn{4}{|c|}{15 years of latency ${ }^{a}$} \\
\hline & & & & & SMR & & $95 \% \mathrm{Cl}$ & \\
\hline \multicolumn{9}{|l|}{ Job title } \\
\hline $\begin{array}{l}\text { Ever autoclave worker } \\
\text { Never autoclave worker b }\end{array}$ & $\begin{array}{l}11 \\
13\end{array}$ & & $\begin{array}{l}896 \\
181\end{array}$ & $\begin{array}{l}447-1603 \\
97-130\end{array}$ & $\begin{array}{r}1358 \\
284\end{array}$ & & $\begin{array}{l}678-2430 \\
151-485\end{array}$ & \\
\hline \multicolumn{9}{|c|}{ Duration of employment (years) } \\
\hline $\begin{array}{l}1-9 \\
10-14 \\
15-19 \\
20-24 \\
\geq 25\end{array}$ & $\begin{array}{l}4 \\
5 \\
4 \\
6 \\
5\end{array}$ & & $\begin{array}{r}94 \\
327 \\
310 \\
714 \\
1111\end{array}$ & $\begin{array}{c}26-239 \\
106-763 \\
84-794 \\
262-1555 \\
361-2593\end{array}$ & $\begin{array}{r}205 \\
602 \\
310 \\
714 \\
1111\end{array}$ & & $\begin{array}{c}56-525 \\
196-1406 \\
84-794 \\
262-1555 \\
361-2593\end{array}$ & \\
\hline \multicolumn{9}{|c|}{ Ranked level of exposure (ppm) } \\
\hline $\begin{array}{l}\text { Low }(<50) \\
\text { Intermediate }(50-499) \\
\text { High }(\geq 500) \\
\text { Unknown }\end{array}$ & $\begin{array}{r}3 \\
3 \\
12 \\
6\end{array}$ & $\begin{array}{r}(4) \\
(7) \\
(12) \\
(1)\end{array}$ & $\begin{array}{l}119 \\
161 \\
567 \\
317\end{array}$ & $\begin{array}{r}25-347 \\
33-471 \\
293-991 \\
117-691\end{array}$ & $\begin{array}{l}227 \\
250 \\
719 \\
486\end{array}$ & $\begin{array}{l}(244) \\
(551) \\
(719) \\
(125)\end{array}$ & $\begin{array}{c}47-664 \\
52-731 \\
371-1255 \\
182-1079\end{array}$ & $\begin{array}{c}(67-625) \\
(222-1136) \\
(371-1255) \\
(3-697)\end{array}$ \\
\hline \multicolumn{9}{|c|}{ Cumulative exposure (ppm-years) } \\
\hline $\begin{array}{l}0-1999 \\
2000-5999 \\
6000-9999 \\
\geq 10000 \\
\text { Unknown }\end{array}$ & $\begin{array}{l}4 \\
4 \\
4 \\
3 \\
9\end{array}$ & $\begin{array}{l}(9) \\
(4) \\
(7) \\
(3) \\
(1)\end{array}$ & $\begin{array}{r}99 \\
351 \\
800 \\
1429 \\
357\end{array}$ & $\begin{array}{c}27-254 \\
96-898 \\
218-2048 \\
295-4175 \\
163-678\end{array}$ & $\begin{array}{r}191 \\
460 \\
851 \\
1667 \\
536\end{array}$ & $\begin{array}{r}(348) \\
(400) \\
(1429) \\
(1667) \\
(100)\end{array}$ & $\begin{array}{c}52-490 \\
125-1177 \\
232-2179 \\
344-4871 \\
245-1017\end{array}$ & $\begin{array}{c}(159-662) \\
(109-1024) \\
(574-2943) \\
(344-4871) \\
(2-557)\end{array}$ \\
\hline Total & 24 & & 286 & $183-425$ & 445 & & $285-663$ & \\
\hline
\end{tabular}

a The values in parentheses were determined in analyses including the estimated job-exposure matrices.

b In Norway, the longest-held job was used. In Sweden job rotation was practiced, and no one was classified as an autoclave worker. 
histology had been performed and this information was available, a liver cancer death could be classified definitely as an angiosarcoma or not. When histology had not been performed or the information was not available, it was classified "unknown" as to whether or not it was an angiosarcoma. Deaths that occurred before 1974 when angiosarcoma of the liver was first reported in relation to VC (19) may not have been investigated as thoroughly as they would have been following the 1974 report. Of the 17 deaths for which histology (pathology) information was available, 16 were histologically confirmed angiosarcomas of the liver and one was a primary liver cancer. For the remaining seven, it is unknown whether or not they were angiosarcomas of the liver. A regression analysis was

Table 6. Maximum likelihood estimates for final model with cumulative exposure and years since first employment for deaths from liver cancer $(\mathrm{N}=24)$. $(95 \% \mathrm{Cl}=95 \%$ confidence in terval)

\begin{tabular}{lrc}
\hline Variable & $\begin{array}{c}\text { Relative } \\
\text { risk }\end{array}$ & $95 \% \mathrm{Cl}$ \\
\hline Cumulative exposure (ppm-years) & & \\
$\quad \quad 500$ & 1.0 & - \\
$\quad 500-1999$ & 1.2 & $0.1-11.4$ \\
$2000-5999$ & 4.6 & $1.0-21.0$ \\
$6000-9999$ & 12.2 & $2.5-59.6$ \\
$\quad \geq 10000$ & 17.1 & $3.1-93.6$ \\
Years since first employment & & \\
$0-19$ & 1.0 & \\
$20-24$ & 5.6 & $1.4-22.4$ \\
$\geq 25$ & 6.8 & $1.7-27.4$ \\
\hline
\end{tabular}

performed to assess the risk of angiosarcoma of the liver. In total, 22 angiosarcomas were included, with 16 coming from the liver cancer deaths coded to ICD 155 (as seen in table 7) and six additional angiosarcomas coming from other deaths, as seen in table 8 . This table shows additional liver cancer deaths, not coded as 155 in the mortality data.

In total, there were six angiosarcomas, one primary liver cancer, and five "unknown" liver cancers among the 12 additional deaths. The small numbers necessitated combining the lowest two categories of cumulative exposure $(<2000 \mathrm{ppm}$-years) for stability of the base-line category. The results were similar to those obtained for the 24 liver cancer deaths in that the final model included years since first exposure and cumulative exposure. The major difference is seen in table 9 , where the relative risks for angiosarcoma are higher at each level of cumulative exposure than those for liver cancer.

The absolute risk of angiosarcoma is shown in table 10 , on the basis of the results of the regression analysis shown in table 9 , when cumulative exposure and years since first exposure were both included in the model. At $\geq 25$ years since first exposure and $\geq 10000$ ppm-years, the absolute risk was 280 per 100000 .

In summary, the results from the regression analyses indicated that, while cumulative exposure and years since first exposure had had a detectable effect on the risk of liver cancer mortality and angiosarcoma of the

Table 7. Characteristics of the 24 subjects who died of liver cancer. (ICD $=$ International Classification of Diseases)

\begin{tabular}{|c|c|c|c|c|c|c|c|c|c|c|}
\hline Subject & $\begin{array}{c}\text { Age } \\
\text { at } \\
\text { hire } \\
\text { (years) }\end{array}$ & $\begin{array}{l}\text { Year of } \\
\text { hire }\end{array}$ & $\begin{array}{l}\text { Duration } \\
\text { of expo- } \\
\text { sure } \\
\text { (years) }\end{array}$ & $\begin{array}{l}\text { Length } \\
\text { of } \\
\text { latency } \\
\text { (years) }\end{array}$ & $\begin{array}{l}\text { Year of } \\
\text { death }\end{array}$ & Cause ${ }^{a}$ & $\begin{array}{l}I C D \\
\text { revision }\end{array}$ & $\begin{array}{c}\text { Angiosarcoma } \\
\text { of the liver }\end{array}$ & $\begin{array}{l}\text { Histologi- } \\
\text { cal con- } \\
\text { firmation } \\
\text { by pathol- } \\
\text { ogy of } \\
\text { angiosar- } \\
\text { coma of } \\
\text { the liver }\end{array}$ & $\begin{array}{c}\text { Total } \\
\text { cumulative } \\
\text { exposure } \\
\text { (ppm-years) }\end{array}$ \\
\hline 1 & 29 & 1955 & 16 & 17 & 1973 & 155.0 & 8 & Unknown & No & 7360 \\
\hline 2 & 27 & 1957 & 13 & 15 & 1972 & 155.0 & 8 & Yes & Yes & 5676 \\
\hline 3 & 21 & 1959 & 21 & 21 & 1981 & 155.0 & 9 & Yes & Yes & 6397 \\
\hline 4 & 47 & 1953 & 14 & 32 & 1985 & 155.0 & 9 & Unknown & No & 7000 \\
\hline 5 & 30 & 1953 & 28 & 31 & 1984 & 155.0 & 9 & No & Yes & 8737 \\
\hline 6 & 41 & 1960 & 8 & 20 & 1980 & 155.0 & 9 & Unknown & No & . \\
\hline 7 & 32 & 1962 & 20 & 21 & 1983 & 155.0 & 9 & Unknown & No & 5493 \\
\hline 8 & 34 & 1950 & 21 & 21 & 1972 & 155.0 & 8 & Yes & Yes & 18407 \\
\hline 9 & 36 & 1947 & 21 & 28 & 1976 & 155.0 & 8 & Yes & Yes & 13770 \\
\hline 10 & 26 & 1941 & 33 & 36 & 1977 & 155.0 & 8 & Yes & Yes & 27709 \\
\hline 11 & 43 & 1961 & 13 & 24 & 1985 & 155.0 & 8 & Yes & Yes & 404 \\
\hline 12 & 45 & 1964 & 10 & 16 & 1980 & 155.0 & 8 & Yes & Yes & 288 \\
\hline 13 & 49 & 1958 & 4 & 18 & 1976 & 155.0 & 8 & Unknown & No & . \\
\hline 14 & 37 & 1951 & 18 & 21 & 1973 & 155.0 & 8 & Unknown & No & 1260 \\
\hline 15 & 33 & 1954 & 18 & 25 & 1979 & 155.2 & 9 & Yes & Yes & 5409 \\
\hline 16 & 20 & 1957 & 27 & 28 & 1985 & 155.2 & 9 & Yes & Yes & 4627 \\
\hline 17 & 35 & 1954 & 24 & 29 & 1983 & 155.0 & 9 & Unknown & No & 111 \\
\hline 18 & 19 & 1968 & 3 & 18 & 1986 & 155.2 & 9 & Yes & Yes & 636 \\
\hline 19 & 36 & 1951 & 21 & 28 & 1979 & 155.2 & 9 & Yes & Yes & 8215 \\
\hline 20 & 26 & 1950 & 25 & 31 & 1981 & 155.2 & 9 & Yes & Yes & 8594 \\
\hline 21 & 30 & 1962 & 10 & 17 & 1980 & 155.2 & 9 & Yes & Yes & 1822 \\
\hline 22 & 24 & 1950 & 31 & 33 & 1983 & 155.2 & 9 & Yes & Yes & 7152 \\
\hline 23 & 37 & 1965 & 16 & 19 & 1985 & 155.2 & 9 & Yes & Yes & 1848 \\
\hline 24 & 18 & 1966 & 4 & 18 & 1984 & 155.0 & 9 & Yes & Yes & 808 \\
\hline
\end{tabular}

a Code of the ICD. 
Table 8. Cases of liver cancer on the basis of cancer incidence and other information (not included as liver cancer deaths in the mortality analysis). (ICD = International Classification of Diseases)

\begin{tabular}{|c|c|c|c|c|c|c|c|c|c|c|c|}
\hline Subject & $\begin{array}{c}\text { Age } \\
\text { at } \\
\text { hire } \\
\text { (years) }\end{array}$ & $\begin{array}{l}\text { Year } \\
\text { of } \\
\text { hire }\end{array}$ & $\begin{array}{l}\text { Dura- } \\
\text { tion of } \\
\text { exposure } \\
\text { (years) }\end{array}$ & $\begin{array}{l}\text { Length } \\
\text { of } \\
\text { latency } \\
\text { (years) }\end{array}$ & $\begin{array}{l}\text { Year of } \\
\text { death }\end{array}$ & Cause $^{a}$ & $\begin{array}{l}I C D \\
\text { revision }\end{array}$ & $\begin{array}{l}\text { Site of incidence } \\
\text { or other information }\end{array}$ & $\begin{array}{l}\text { Angio- } \\
\text { sarcoma } \\
\text { of the } \\
\text { liver }\end{array}$ & $\begin{array}{l}\text { Histologi- } \\
\text { cal confir- } \\
\text { mation by } \\
\text { pathology }\end{array}$ & $\begin{array}{l}\text { Total } \\
\text { cumulative } \\
\text { exposure } \\
\text { (ppm-years) }\end{array}$ \\
\hline 1 & 24 & 1951 & 19 & 19 & 1970 & 197.8 & 8 & Cancer incidence: ICD 155.0 & Yes & Yes & 8203 \\
\hline 2 & 45 & 1961 & 6 & 8 & 1970 & 197.8 & 8 & $\begin{array}{l}\text { Death certificate: carcinoma } \\
\text { of liver }\end{array}$ & Unknown & No & . \\
\hline 3 & 28 & 1966 & 8 & 8 & 1974 & 197.8 & 8 & $\begin{array}{l}\text { Death certificate: carcinoma } \\
\text { of liver, angiosarcoma, } \\
\text { hepatic cirrhosis }\end{array}$ & Yes & Yes & 1749 \\
\hline 4 & 34 & +965 & 10 & 12 & 1977 & 197.8 & 8 & $\begin{array}{l}\text { Death certificate: hepatic } \\
\text { failure due to liver cancer }\end{array}$ & Unknown & No & $\cdots$ \\
\hline 5 & 18 & 1965 & 7 & $?$ & Emigrated & - & - & Cancer incidence: ICD 155.0 & No & Yes & $\cdots$ \\
\hline 6 & 36 & 1957 & 7 & 7 & 1964 & 199.0 & & $\begin{array}{l}\text { Best evidence (clinical): } \\
\text { ICD } 155.0\end{array}$ & Unknown & No & . \\
\hline 7 & 50 & 1954 & 11 & 11 & 1965 & 199.0 & 8 & $\begin{array}{l}\text { Best evidence (clinical): } \\
\text { ICD } 155.0\end{array}$ & Unknown & No & $\cdots$ \\
\hline 8 & 54 & 1969 & 9 & 10 & 1980 & 199.0 & 9 & Cancer incidence: ICD 155.2 & Unknown & No & $\cdots$ \\
\hline 9 & 29 & 1941 & 31 & 31 & 1972 & 157.9 & 8 & Cancer incidence: ICD 155.0 & Yes & Yes & 28156 \\
\hline 10 & 32 & 1953 & 20 & 22 & 1975 & 159.0 & 8 & $\begin{array}{l}\text { Best evidence (pathology): } \\
\text { ICD } 155.0\end{array}$ & Yes & Yes & 7673 \\
\hline 11 & 43 & 1944 & 22 & 28 & 1972 & 227.0 & 8 & $\begin{array}{l}\text { Death certificate: } \\
\text { hemangioendothelioma of } \\
\text { liver, natural causes }\end{array}$ & Yes & Yes & 7114 \\
\hline 12 & 42 & 1963 & 8 & 17 & 1980 & 571.5 & 9 & $\begin{array}{l}\text { Death certificate: } \\
\text { hepatic failure due } \\
\text { to hepatic fibrosis }\end{array}$ & Yes & Yes & 2658 \\
\hline
\end{tabular}

a According to the ICD.

liver, age at first exposure and calendar period of exposure did not. Very clear exposure-response relationships were evident between the cumulative exposure to $\mathrm{VC}$ and the risk of liver cancer and angiosarcoma of the liver. Finally, an effect of misclassification was demonstrated when the estimated job-exposure matrix was included, although the effect was minimal for the angiosarcoma results.

\section{Lung cancer, brain cancer and lymphosarcoma}

The SMR for trachea, bronchus, and lung cancer was $97(95 \% \mathrm{CI} 82-114)$ for the total cohort, on the basis of 144 observed deaths. The SMR values did not show any remarkable association with a particular process, and although no pattern was evident for years since first exposure, there was a statistically significant increase at 25-29 years since first exposure on the basis of 33 observed deaths (SMR 147, $95 \%$ CI 101207), mainly from an excess in VCM production in this time period ( 5 deaths observed, SMR 486, $95 \% \mathrm{CI}$ 158-1134). Calendar period at exit and at hire did not reveal any consistent pattern.

Fourteen deaths from brain cancer occurred in the cohort, and, although the overall SMR was not increased (SMR 107, $95 \%$ CI 59-180), there was a statistically significant excess at $\geq 30$ years since first exposure on the basis of four observed deaths (SMR 407, $95 \%$ CI 111-1041) (table 4). The excess was confined to the calendar period of hire of 1945-1954 and was the most evident for VCM/PVC production. Analyses by calendar period of exit, age at hire, and age at exit did not reveal any patterns of risk for brain cancer mortality.
Table 9. Maximum likelihood estimates for the final model with cumulative exposure and years since first employment for the deaths from angiosarcoma of the liver $(\mathrm{N}=22)$. (95\% $\mathrm{Cl}=95 \%$ confidence interval)

\begin{tabular}{lrc}
\hline Variable & $\begin{array}{c}\text { Relative } \\
\text { risk }\end{array}$ & $95 \% \mathrm{Cl}$ \\
\hline Cumulative exposure (ppm-years) & & \\
$\quad<2000$ & 1.0 & \\
$2000-5999$ & 6.8 & $1.1-41.7$ \\
$\quad 6000-9999$ & 24.7 & $4.1-150.1$ \\
$\quad \geq 10000$ & 45.4 & $7.3-281.1$ \\
Years since first employment & & \\
$0-19$ & 1.0 &. \\
$20-24$ & 4.7 & $1.0-22.8$ \\
$\geq 25$ & 6.2 & $1.4-29.0$ \\
\hline
\end{tabular}

Table 10. Absolute risk of angiosarcoma of the liver per 100000 .

\begin{tabular}{lcccc}
\hline $\begin{array}{l}\text { Years since } \\
\text { first }\end{array}$ & \multicolumn{4}{c}{ Cumulative exposure (ppm-years) } \\
\cline { 2 - 5 } employment & $<2000$ & $2000-5999$ & $6000-9999$ & $\geq 10000$ \\
\hline $0-19$ & 1.0 & 6.8 & 24.4 & 44.8 \\
$20-24$ & 4.7 & 32.0 & 115.6 & 212.5 \\
$\geq 25$ & 6.2 & 42.2 & 152.3 & 280.0 \\
\hline
\end{tabular}

A detailed analysis of the seven deaths from lymphosarcoma showed no pattern in the SMR values according to years since first exposure. All seven deaths occurred in VCM/PVC production, and for this process alone there was no excess apparent by calendar period of hire or exit or age at hire or exit. 
In table 11, the SMR values for lung cancer, and in table 12 those for brain cancer and lymphosarcoma, are shown according to the exposure variables. The analyses by job title, duration of employment, and cumulative exposure showed no relationship with any of the three sites. Neither was lung cancer associated with the ranked level of exposure, while brain cancer was slightly in excess in the high category of exposure. Lymphosarcoma showed a slight increasing pattern of mortality with increasing category of ranked level of exposure, but the entire analysis was based on four deaths only.

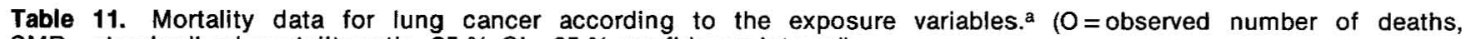
SMR $=$ standardized mortality ratio, $95 \% \mathrm{Cl}=95 \%$ confidence interval)

\begin{tabular}{|c|c|c|c|c|c|c|}
\hline Exposure variable & $\mathrm{O}^{\mathrm{a}}$ & & $\mathrm{SMR}^{\mathrm{a}}$ & & $95 \% \mathrm{Cl}^{\mathrm{a}}$ & \\
\hline \multicolumn{7}{|l|}{ Job title } \\
\hline $\begin{array}{l}\text { Ever autoclave worker } \\
\text { Never autoclave workerb }\end{array}$ & $\begin{array}{r}25 \\
119\end{array}$ & & $\begin{array}{l}97 \\
97\end{array}$ & & $\begin{array}{l}63-143 \\
80-116\end{array}$ & \\
\hline \multicolumn{7}{|c|}{ Duration of employment (years) } \\
\hline $\begin{array}{l}1-9 \\
10-19 \\
\geq 20\end{array}$ & $\begin{array}{l}73 \\
51 \\
20\end{array}$ & & $\begin{array}{r}95 \\
107 \\
83\end{array}$ & & $\begin{array}{l}75-120 \\
79-140 \\
51-129\end{array}$ & \\
\hline \multicolumn{7}{|c|}{ Ranked level of exposure (ppm) } \\
\hline $\begin{array}{l}\text { Low }(<50) \\
\text { Intermediate }(50-499) \\
\text { High }(\geq 500) \\
\text { Unknown }\end{array}$ & $\begin{array}{l}37 \\
33 \\
35 \\
39\end{array}$ & & $\begin{array}{r}94 \\
116 \\
98 \\
87\end{array}$ & & $\begin{array}{l}66-130 \\
80-163 \\
68-136 \\
62-119\end{array}$ & \\
\hline \multicolumn{7}{|c|}{ Cumulative exposure (ppm-years) } \\
\hline $\begin{array}{c}<50 \\
50-499 \\
500-1999 \\
2000-5999 \\
6000-9999 \\
\geq 10000 \\
\text { Unknown } \\
\end{array}$ & $\begin{array}{r}20 \\
32 \\
14 \\
11 \\
7 \\
2 \\
58\end{array}$ & $\begin{array}{r}(37) \\
(49) \\
(18) \\
(16) \\
(10) \\
(2) \\
(12)\end{array}$ & $\begin{array}{r}98 \\
101 \\
101 \\
83 \\
141 \\
106 \\
93\end{array}$ & $\begin{array}{r}(110) \\
(101) \\
(85) \\
(74) \\
(152) \\
(94) \\
(80)\end{array}$ & $\begin{array}{l}60-151 \\
69-143 \\
55-169 \\
42-149 \\
57-290 \\
13-384 \\
71-120\end{array}$ & $\begin{array}{l}(77-151) \\
(75-134) \\
(51-135) \\
(43-121) \\
(73-280) \\
(11-339) \\
(41-139)\end{array}$ \\
\hline Total & 144 & & 97 & & $82-114$ & \\
\hline
\end{tabular}

a The values in parentheses were determined in analyses including the estimated job-exposure matrices.

b In Norway, the longest-held job was used. In Sweden job rotation was practiced, and no one was classified as an autoclave worker.

Table 12. Mortality data for brain cancer and lymphosarcoma according to the exposure variables. $(0=$ observed number of deaths, SMR = standardized mortality ratio, $95 \% \mathrm{Cl}=95 \%$ confidence interval)

\begin{tabular}{|c|c|c|c|c|c|c|}
\hline \multirow{2}{*}{ Exposure variable } & \multicolumn{3}{|c|}{ Brain cancer } & \multicolumn{3}{|c|}{ Lymphosarcoma } \\
\hline & 0 & SMR & $95 \% \mathrm{Cl}$ & 0 & SMR & $95 \% \mathrm{Cl}$ \\
\hline \multicolumn{7}{|l|}{ Job title } \\
\hline $\begin{array}{l}\text { Ever autoclave worker } \\
\text { Never autoclave worker }\end{array}$ & $\begin{array}{r}2 \\
12\end{array}$ & $\begin{array}{r}85 \\
112\end{array}$ & $\begin{array}{l}10-307 \\
58-196\end{array}$ & $\begin{array}{l}3 \\
4\end{array}$ & $\begin{array}{l}661 \\
147\end{array}$ & $\begin{array}{c}136-1931 \\
40-377\end{array}$ \\
\hline Duration of employment (years) & & & $\cdot$ & & & \\
\hline $\begin{array}{l}1-9 \\
10-19 \\
\geq 20\end{array}$ & $\begin{array}{l}8 \\
3 \\
3\end{array}$ & $\begin{array}{r}106 \\
78 \\
183\end{array}$ & $\begin{array}{l}46-208 \\
16-228 \\
38-535\end{array}$ & $\begin{array}{l}6^{b} \\
1 \\
-\end{array}$ & $\begin{array}{r}484 \\
116 \\
0\end{array}$ & $\begin{array}{c}178-1053 \\
3-648 \\
0-1230\end{array}$ \\
\hline \multicolumn{7}{|l|}{ Ranked level of exposure (ppm) } \\
\hline $\begin{array}{l}\text { Low }(<50) \\
\text { Intermediate }(50-499) \\
\text { High }(\geq 500) \\
\text { Unknown }\end{array}$ & $\begin{array}{l}3 \\
1 \\
4 \\
6\end{array}$ & $\begin{array}{r}91 \\
42 \\
128 \\
141\end{array}$ & $\begin{array}{r}19-265 \\
1-235 \\
35-328 \\
52-306\end{array}$ & $\begin{array}{l}1 \\
1 \\
2 \\
3\end{array}$ & $\begin{array}{l}127 \\
176 \\
234 \\
310\end{array}$ & $\begin{array}{r}3-705 \\
4-983 \\
28-846 \\
64-907\end{array}$ \\
\hline \multicolumn{7}{|l|}{ Cumulative exposure (ppm-years) } \\
\hline $\begin{array}{l}\quad<50 \\
50-499 \\
\geq 500 \\
\text { Unknown }\end{array}$ & $\begin{array}{l}- \\
4 \\
4 \\
6\end{array}$ & $\begin{array}{r}0 \\
162 \\
120 \\
110\end{array}$ & $\begin{array}{r}0-204 \\
44-414 \\
33-308 \\
40-239\end{array}$ & $\begin{array}{l}1 \\
1 \\
1 \\
4\end{array}$ & $\begin{array}{l}233 \\
156 \\
142 \\
288\end{array}$ & $\begin{array}{r}6-1296 \\
4-868 \\
4-794 \\
78-736 \\
\end{array}$ \\
\hline Total & 14 & 107 & $59-180$ & 7 & 221 & $89-455$ \\
\hline
\end{tabular}

a In Norway, the longest-held job was used. In Sweden job rotation was practiced, and no one was classified as an autoclave worker.

b All six deaths in the periods $1-4$ years. 
Cancer of unspecified site

Twenty-four deaths in the cohort were classified as malignant neoplasms of unspecified sites (ICD 199), giving a statistically significant excess ( 24 deaths observed, SMR 187, $95 \%$ Cl 120-278). Additional information, such as cancer incidence data, was available for 20 of the 24 deaths. Three subjects had liver cancer and were therefore included in table 8 . It was unknown, however, whether they had angiosarcoma of the liver since no histological information was available. No other clear excess of a particular cancer among those classified as cancer deaths of an unspecified site was apparent.

\section{Cancer incidence results}

For the 2643 subjects from the four factories in Norway and Sweden included in the cancer incidence analysis, the total number of cancers observed was 127 (SIR $107,95 \%$ CI $89-127$ ), and their distribution by site is shown in table 13 (reported for one or more observed deaths). The only statistically significant excess was for liver cancer, on the basis of seven observed cases (SIR 303, $95 \%$ CI 122-623). Suggestive increases were found for stomach cancer (13 cases observed, SIR 150, $95 \%$ CI 80-256), lung cancer (22 cases observed, SIR 152, $95 \%$ CI 95-230), melanoma ( 8 cases observed, SIR 184, $95 \%$ CI 79-362), and brain cancer ( 8 cases observed, SIR 159, $95 \%$ CI, 68-312).

Although the lung cancer increase was not statistically significant, it was investigated in more detail as other studies have suggested increased risk for lung cancer. There was no excess according to process type or category of years since first exposure. A slight excess was suggested for $<15$ years of employment, while the SIR values were close to 100 for $15-19$ and $\geq 20$ years of employment. For the ranked level of exposure, the risks in the high and low categories were virtually identical. According to cumulative exposure, no exposure-response was apparent (results not presented in tabular form). Without statistical significance and with little apparent relationship to VC exposure, some indication of increased lung cancer risk remained for one PVC-processing plant and one Norwegian VCM/ PVC production plant. The national investigator for the PVC-processing plant attributed the excess to exposure to asbestos, which was utilized in the process (7), while the excess remained unexplained in Norway.

\section{Discussion}

This collaborative study was carried out with the main purpose of analyzing exposure-response relationships between exposure to $\mathrm{VC}$ and liver cancer and investigating whether exposure to VC could increase cancer risk for sites other than the liver.
The results confirmed the association between exposure to VC and liver cancer. The excess of liver cancer mortality was associated with duration of employment, and a clear association with ranked level of exposure was found. The results were strengthened by the regression analyses, which indicated that the risk of liver cancer depended on cumulative exposure and years since first exposure.

Twenty-two subjects had histologically confirmed angiosarcoma of the liver, and the regression analyses demonstrated that the risk was mostly influenced by cumulative exposure to $\mathrm{VC}$. The relative risks were higher at each level of cumulative exposure than those for all liver cancer deaths, but it must be remembered that the same 16 angiosarcoma deaths were included in both analyses. The approximate incidence rate of angiosarcoma of the liver in Norway, for example, based on 1953 - 1988 data, was 1 in 10 million per year (personal communication from A Andersen, 1989). Others have estimated the annual incidence at 1 to 2 in 10 million $(20,21)$.

Given 222746 person-years at risk accumulated by this cohort, with an annual incidence of angiosarcoma of the liver of 2 per 10 million in the general population, the overall expected figure for the cohort would be $\mathbf{0 . 0 4 5}$. The rarity of this tumor supports the use of internal comparisons to assess the significance of exposure variables.

Table 13. Cancer incidence, based on data for four factories in Norway and Sweden, by detailed cause. $(\mathrm{O}=$ observed number of cases, $E=$ expected number of cases, SIR = standard ized incidence ratio, $95 \% \mathrm{Cl}=95 \%$ confidence interval)

\begin{tabular}{|c|c|c|c|c|}
\hline Cancer site ${ }^{a}$ & 0 & $\mathbf{E}$ & SIR & $95 \% \mathrm{Cl}^{\mathrm{b}}$ \\
\hline $\begin{array}{l}\text { Buccal cavity and pharynx } \\
(140-148)\end{array}$ & 5 & 4.2 & 119 & $39-277$ \\
\hline Stomach (151) & 13 & 8.7 & 150 & $80-256$ \\
\hline $\begin{array}{l}\text { Intestine, except rectum } \\
(152-153)\end{array}$ & 8 & 8.9 & 89 & $39-176$ \\
\hline Rectum (154) & 2 & 5.9 & 34 & $4-123$ \\
\hline $\begin{array}{l}\text { Liver and intrahepatic bile } \\
\text { ducts (155) }\end{array}$ & 7 & 2.3 & 303 & $122-623$ \\
\hline Pancreas (157) & 3 & 4.3 & 70 & $14-203$ \\
\hline Larynx (161) & 2 & 1.6 & 122 & $15-441$ \\
\hline $\begin{array}{l}\text { Trachea, bronchus and lung } \\
\text { (162) }\end{array}$ & 22 & 14.5 & 152 & $95-230$ \\
\hline Melanoma of skin $(190)$ & 8 & 4.4 & 184 & $79-362$ \\
\hline Prostate (177) & 16 & 18.0 & 89 & $51-144$ \\
\hline Testis (178) & 1 & 2.2 & 45 & $1-252$ \\
\hline Bladder (181) & 7 & 7.9 & 88 & $36-182$ \\
\hline Kidney $(180)$ & 4 & 5.4 & 74 & $20-188$ \\
\hline Brain (193) & 8 & 5.1 & 159 & $68-312$ \\
\hline Thyroid (194) & 3 & 0.9 & 327 & $67-955$ \\
\hline $\begin{array}{l}\text { Lymphosarcoma and other } \\
\text { lymphoma }(200,202)\end{array}$ & 1 & 3.6 & 28 & $1-154$ \\
\hline Multiple myeloma (203) & 1 & 1.9 & 53 & $1-297$ \\
\hline Other malignant neoplasms & 16 & 11.9 & 135 & $77-219$ \\
\hline $\begin{array}{l}\text { All malignant neoplasms } \\
(140-205)\end{array}$ & 127 & 119.0 & 107 & $89-127$ \\
\hline
\end{tabular}

a Code of the International Classification of Diseases in parentheses. b Based on a Poisson distribution. 
The exposure estimates used for the ranked level of exposure and cumulative exposure indices were based on the reconstruction of past exposures, and they appeared to be an efficient tool for investigating exposure-response relationships. Although the job-exposure matrices utilized for the analysis were often based on rough estimates and thus resulted in a certain degree of imprecision, the results demonstrate exposure-response relationships for the carcinogenicity of VC. A recent study also estimated cumulative exposure to VCM, PVC, and butadiene and found that only cumulative exposure to VCM had any effect on liver cancer risk (6).

No increase was evident for lung cancer mortality, nor was there any association with the exposure variables, including ranked and cumulative exposure indices. It should be noted that the power of the study would allow detection of a statistically significant (at the $5 \%$ level, one-sided) SMR for lung cancer of 114 with $80 \%$ probability.

A slight increase in lung cancer was suggested by the incidence data, which corresponded to about $10 \%$ of the mortality data. There was no apparent relation between lung cancer incidence and VC exposure. In one factory of the four included in the incidence analysis, a case of pleural mesothelioma was reported, and exposure to asbestos has been documented for the PVCprocessing plant (7).

Two other sites investigated for excess risk were brain cancer and lymphosarcoma according to the a priori hypotheses. The results from this collaborative study did not suggest an effect of exposure to VC on mortality from brain cancer, although the power of the study only permitted detection of an SMR of 182 or more, which could be labeled as statistically significant with $80 \%$ probability. The excess at $\geq 30$ years since first employment was, however, an indication that an effect of exposure cannot be fully dismissed. For lymphosarcoma, although an excess was suggested, the small numbers and missing information on exposure variables for some of the subjects prohibited interpretation in relation to exposure to VC.

None of the other causes of death was in excess; instead, some statistically significant deficits were apparent. The deficit in total mortality was probably due to the healthy worker effect, both in the hiring of healthy workers compared with the general population and in a survival effect within the cohort due to the criteria for inclusion of employment for one year or more.

These results are very similar to those reported recently in the United States (6). In that study only liver cancer was in excess for the cohort of VCM workers (SMR 333, $95 \%$ CI 202-521), with no statistically significant excess of lung cancer (SMR 115, $95 \% \mathrm{CI}$ 95-139), brain cancer (SMR 145, $95 \%$ CI 79-248) or hematopoietic cancers (SMR 78, $95 \% \mathrm{CI} 48-121$ ). In the nested case-referent analysis, liver cancer risk increased with increasing cumulative exposure (esti- mated as duration times categorized exposure level). Of the 19 liver cancers, 12 were angiosarcomas, and for this subgroup only, unlike our results, was the positive dose-response evident.

\section{Concluding remarks}

The results of this multicentric collaborative study on workers in the VC industry indicate that exposure to $\mathrm{VC}$ is associated with an increase in liver cancer. An exposure-response relationship was observed for both ranked and estimated cumulative exposure. The relationship was even more evident when only liver angiosarcoma was analyzed.

No significant excess of mortality was found for the other sites suspected a priori to be affected by exposure to VC. Although the incidence of lung cancer was slightly increased, neither it nor lung cancer mortality appeared to be associated with any of the exposure variables. Brain cancer and lymphosarcoma mortality, although showing slight increases, did not appear to be consistently associated with exposure, although the small numbers prohibited firm conclusions.

An increased risk of bladder cancer and melanoma of the skin was detected which did not appear to be related to exposure in that the association with employment in the VC industry was confined to one country only.

No increased mortality was observed for the other main causes of death.

\section{Acknowledgments}

We are deeply indebted to Mr E Ljunggren from Nobel Industrier Sverige, Sundsvall, Sweden, and to Mr B Mountfield from ICI Chemicals and Polymers Ltd, Macclesfield, the United Kingdom, for their contribution to the estimation of past exposure levels of VC. The following people from IARC are thanked for their contributions: Mr A Barbin, Ms B Charnay, Ms A Hanss-Cousseau, and Dr M Kogevinas. Ms E Zanellato, from the Registro Tumori del Veneto, edited and typed the final manuscript. The analysis for this study was undertaken during the tenure of a research training fellowship awarded to Dr KA L'Abbé by IARC.

\section{References}

1. International Agency for Research on Cancer (IARC). Some monomers, plastics, and synthetic elastomers and acrolin. Lyon: IARC, 1979. (IARC monographs on the evaluation of the carcinogenic risk of chemicals to humans; vol 19.)

2. International Agency for Research on Cancer (IARC). Overall evaluations of carcinogenicity: an updating of IARC monographs volumes 1 to 42. Lyon: IARC, 1987. (IARC monographs on the evaluation of the carcinogenic risk of chemicals to humans; suppl 7.)

3. Viola PL. Pathology of vinyl chloride. In: Proceedings of the 16th International Congress on Occupational 
Health, Tokyo: Japan Organizing Committee, 1969: 296-7.

4. Barbin A, Bartsch $\mathrm{H}$. Mutagenic and promutagenic properties of DNA adducts formed by vinyl chloride metabolites. In: Singer B, Bartsch $\mathrm{H}$, ed. The role of cyclic nucleic acid adducts in carcinogenesis and mutagenesis. Lyon: International Agency for Research for Cancer, 1986:345-358. (IARC scientific publication; no 70.)

5. Jones RD, Smith DM, Thomas PG. A mortality study of vinyl chloride monomer workers employed in the United Kingdom in 1940-1974. Scand J Work Environ Health 1988;14:153-60.

6. Wu W, Steenland K, Brown D, Wells V, Jones J, Schulte $\mathrm{P}$, Halperin W. Cohort and case-control analyses of workers exposed to vinyl chloride: an update. J Occup Med 1989;31:518-23.

7. Hagmar L, Akesson B, Nielson J, et al. Mortality and cancer morbidity in workers exposed to low levels of vinyl chloride monomer at a polyvinyl chloride processing plant. Am J Ind Med 1990;17;553-66.

8. Doll R. Effects of exposure to vinyl chloride: an assessment of the evidence. Scand J Work Environ Health, 1988; 14:61-78.

9. L’Abbé KA, Ferro G, Winkelmann R, Saracci R, Simonato L. Mortality and cancer incidence results of the European multi-centric cohort study of workers employed in the vinyl chloride industry. Lyon: International Agency for Research on Cancer, 1989. (IARC internal report; no 89/007.)

10. Byren D, Engholm G, Englund A, Westerholm P. Mortality and cancer morbidity in a group of Swedish VCM and PVC production workers. Environ Health Perspect 1976;17:167-70.

11. Molina G, Homberg B, Elofsson S, Holmlund L, Maasing R, Westerholm P. Mortality and cancer rates among workers in the Swedish PVC processing indus- try. Environ Health Perspect 1981;41:145-51.

12. Storetvedt Heldaas S, Langård SL, Andersen A. Incidence of cancer among vinyl chloride and polyvinyl chloride workers. Br J Ind Med 1984;41:25-40.

13. Jones JH. Worker exposure to vinyl chloride and poly(vinylchloride). Environ Health Perspect 1981;41: 129-36.

14. Belli S, Bertazzi PA, Comba P, et al. A cohort study on vinyl chloride manufacturers in Italy: study design and preliminary results. Cancer Lett 1987;35:253-61.

15. Pirastu R, Comba P, Reggiani A, Foa V, Masina A, Maltoni C. Mortality from liver disease among Italian vinyl chloride monomer/polyvinyl chloride manufacturers. Am J Ind Med 1990;17:155-61.

16. Coleman MP, Hermon C, Douglas A. Person-years (PYRS); a Fortran program for cohort study analysis. Lyon: International Agency for Research on Cancer, 1989. (IARC internal report; no $89 / 006$.)

17. Breslow NE, Day NE. Statistical methods in cancer Research; vol II (The design and analysis of cohort studies). Lyon: International Agency for Research on Cancer, 1987. (IARC scientific publications; no 82.)

18. Baker RJ. Glim 3.77: Reference manual. Oxford: Numerical Algorithms Group, 1985.

19. Creech JL, Johnson MN. Angiosarcoma of liver in the manufacture of polyvinyl chloride. J Occup Med 1974; $16: 150-1$.

20. Brady J, Liberatore F, Harper P, et al. Angiosarcoma of the liver: an epidemiologic survey. J Natl Cancer Inst 1977;59:1383-5.

21. Byren D, Holmberg B. Two possible cases of angiosarcoma of the liver in a group of Swedish vinyl chloride workers. Ann NY Acad Sci 1975;246:249-50.

Received for publication: 18 October 1990 